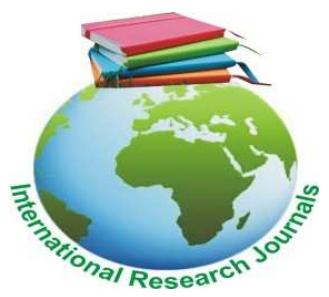

Educational Research (ISSN: 2141-5161) Vol. 8(1) pp. 006-008, January, 2017

Available online@ http://www.interesjournals.org/ER

DOI: http:/dx.doi.org/10.14303/er.2017.017

Copyright (C) 2017 International Research Journals

Review

\title{
Need for cost-benefit analysis, productivity and efficiency in education
}

\author{
Paul Nwakpa \\ Department of Educational Foundations, Faculty of Education, Ebonyi State University, Abakaliki, Nigeria \\ Corresponding Author's E-mail: bropaulnwaoo@ gmail.com
}

\begin{abstract}
Need for cost-benefit analysis, productivity and efficiency in education has actually been $x$-rayed systematically, the various key words were precisely explained for a layman to understand. The social aspect of cost-benefit analysis, measurement of productivity, issues connected with productivity and efficiency, link between productivity and efficiency, low external productivity in the face of high internal efficiency and relationship between external productivity and cost benefit ratio were highlighted. Finally, conclusion and recommendations were made.
\end{abstract}

Keywords: Cost-benefit, Education, Productivity, Efficiency.

\section{INTRODUCTION}

The understanding of Cost-Benefit analysis, productivity and efficiency in education by the education stake holders will act as boaster to the growth and development of education in any economy. The three concepts costbenefit analysis, productivity and efficiency will ginger the operators in education industry to perform at their best and make them to be result oriented.

\section{Cost-benefit analysis}

Nwakpa (2013) saw Cost-Benefit Analysis as a technique for describing, quantifying and comparing costs and benefits of investment projects in order to determine whether, or to what extent those progress are worthwhile. There are four major steps in the process of comparing costs benefits of a project. There are:

(1) Identification of all advantages and disadvantages of a project

(2) Quantification of identified merits and demerits so as to place numerical value on each cost and each benefit.

(3) Monetarization of the quantified merits and demerits so as to bring all quantifiable costs and benefits to a common denominator of money.

(4) Aggregation of moneterized costs and benefits using appropriate formulae which include (a) Net present value(NPV), (b) Internal Rate of Returns (IRR) and (c) Benefit Cost Ratio (BCR).

\section{Social aspect of cost benefit analysis}

Babalola (2003) was of the opinion that cost-benefit analysis has both private and social aspects, when an individual wishes to establish an industry, he may want to know the costs and the benefits of such an industry and the differences between the costs and the benefits (Net benefit). If the value of the benefits is greater than the value of the costs, the investor will consider the project worthwhile. But if the value of the benefits is the same with the or less than the value of the costs, he may decide not to embark on such project because such project brings no gain. What matters to the private investors is whether or not the project is worthwhile. He is not primarily concerned with what the society will gain or lose from such an investment. Cost benefit analysis must not only identify and quantify private cost and benefit, it must also measure social costs and benefits. That is, it must concern itself with what will be the positive and negative effects of the project on the society as a whole. For instance, an investor must not only concern himself with the private net benefit of establishing an industrial waste industry. He must also concern himself with the net benefit to the society. It is the social aspect of cost benefit analysis that distinguishes it from ordinary investment appraisal method or feasibility study.

Productivity according to Oguntoye (2002) denotes the relationship between output and one or all associated 
Nwakpa, 007

Table showing distinctions between immediate outputs and ultimate benefits of education

\begin{tabular}{|c|c|c|c|}
\hline & Criterion & Immediate output & Ultimate benefit \\
\hline (1) & Composition & $\begin{array}{l}\text { Composed of all that a graduate } \\
\text { acquired in the process of being } \\
\text { educated. For example, all the acquired } \\
\text { learning skills and attitudes that students } \\
\text { carry away from the educational system } \\
\text { when they brought it initially. }\end{array}$ & $\begin{array}{l}\text { Composed of all that can be gained through the } \\
\text { application of the skills, learning and attitude } \\
\text { acquired by graduates. For example, better jobs, } \\
\text { higher income, more satisfying, family life, greater } \\
\text { sense of participation, higher productivity, better } \\
\text { living standards, supply of more effective leaders } \\
\text { etc. }\end{array}$ \\
\hline (2) & Connotation & $\begin{array}{l}\text { Connotes learning achievement on the } \\
\text { difference between entry and exit } \\
\text { behaviours of graduates. }\end{array}$ & $\begin{array}{l}\text { Connotes advantages of education both individuals } \\
\text { and the society. It concerns the relevance of the } \\
\text { knowledge, skills and attitude acquired while in } \\
\text { school. }\end{array}$ \\
\hline (3) & Measurement. & $\begin{array}{c}\text { Examination results can be used to } \\
\text { measure the difference between what } \\
\text { students carry away from the educational } \\
\text { system and what they brought to it } \\
\text { initially. The number of graduates can } \\
\text { also be compared with the number who } \\
\text { were admitted initially. The rate of drop } \\
\text { out can therefore affect immediate } \\
\text { output. }\end{array}$ & $\begin{array}{c}\text { Both qualitative and quantitative measures of the } \\
\text { difference education has made in the life of the } \\
\text { graduates and in the economy. Economic measures } \\
\text { used include life time earnings, increased } \\
\text { productivity and tax contribution resulting from the } \\
\text { education acquired. }\end{array}$ \\
\hline
\end{tabular}

input in real terms. It may be defined simply as output per unit or input. The concept of productivity is based on the notion of production function which states that the volume of output depends on the volume of inputs used in production and on the state of the art or technology. The purpose of productivity measurement is to provide a yardstick of economic efficiency in different time periods for individual firm within an industry. Productivity is to ensure that outputs are increased while inputs are kept static or even reduced.

\section{Measurement of productivity}

The following steps should be taken in order to measure productivity of a firm or an industry.

(1) Definition of all inputs and outputs.

(2) Measurement of all inputs and outputs in qualitative terms.

(3) Isolation of variation in quality of outputs and inputs.

(4) Expression of inputs and outputs in real term.

(5) Combination of various real inputs and outputs into a single index.

(6) Division of outputs by inputs.

\section{Efficiency}

Simon 1945 in Nwakpa (2013) defines efficiency in layman's term as the ability to produce the desired effect with minimum of effort, expense or waste. The criterion of efficiency demand that, of two alternatives the same cost one be chosen which will lead to a greater attainment of the organizational objectives. It also demands that of two alternatives leading to the same degree of attainment is one being chosen which entails the lesser cost. On one hand and efficiency involves the maximization of outputs, if inputs are considered as fixed, and on the other hand, the minimization of inputs if outputs are considered as fixed. It is concerned with the maintenance of a positive balance of output over input.

\section{Link between productivity and efficiency}

It is through maximized productivity that maximum efficiency is achieved. The higher the output per input the higher the ability to produce the desired effect with minimum input and vice-versa. As earlier stated, the essence of productivity measurement is to provide a yardstick of efficiency. Two ways by which productivity can be maximized by an organization and therefore achieve maximum efficiency are listed below:(1) Any given set of inputs should be utilized so as to produce the largest value of output.(2) For a specified output and quality level, inputs should be chosen and utilized in order to minimize production costs.

\section{Issues connected with productivity and efficiency in education}

Distinctions between Immediate Outputs and Ultimate Benefits of Education. The distinctions layed out in the table above must be made between immediate outputs and ultimate benefits of education in order to understand the difference between productivity and efficiency in education. 
008 Educ. Res.

\section{Low external productivity in the face of high internal efficiency}

An educational system can have high internal efficiency yet low external productivity. This can happen when there is high learning achievement or added value but low socio-economic impact of the knowledge, skill and attitude acquired in the education system. May be the educational system is producing graduates with little or no repetition or dropout, and at the same time wrong things have been taught. The education is not relevant to either the needs of the students or that of the society.

Specialist in educational management may have been trained but if too few jobs are available in that field, the investment in their training is likely to produce few benefits. Thus, the relevance and fitness of what an educational system teaches it's students at a particular time and place has a major bearing on the system's ultimate productivity.

I will want to emphasize the point that ultimate productivity may also be affected by the inability of the economy to effectively put into use the knowledge, skills and attitude acquired by students in the process of their education. A relevant course may attract little or no benefit if the economy does not create job opportunity for the graduates or the school leavers.

\section{Relationship between external productivity and cost- benefit ratio}

Cost-Benefit Ratio of an educational system is an indicator of the external productivity according to Adeogun (1999). External productivity relates cost of producing learning results in a particular period with the cumulative benefits that subsequently accrue from those learning results over a long period. Similarly, cost-benefit ratio is the relationship between the cost of producing results (output) and the cumulative benefits of education. If the accrued benefits to individual and society substantially exceed the educational costs, then that particular educational effort can be viewed as a good investment.

\section{CONCLUSION}

The knowledge of Cost-Benefit Analysis, Productivity and Efficiency to the education stake holders in Nigeria and beyond needs not to be over emphasized. It equips all the actors in the education sector for optimal performance. Cost benefit analysis enables one to actually invest or not in a particular project or programme and if eventually invested in a project, it makes one work very hard in order to achieve his goal. So it is a worthwhile topic for investors in any organization.

\section{RECOMMENDATION}

The importance of this topic makes the writer to recommend the following:

(1) It is important that every investor must know the cost and benefit of any project before embarking on it.

(2) Every investor must be made to know that without high level of productivity that he will not achieve his goals or make profits (benefits).

(3) That high level of productivity cannot easily be achieved without high level of efficiency. Thus, efficient workers are required in every organization in order to achieve high productivity and benefit.

\section{REFERENCES}

Adeogun AA (1999). School plant planning and facilities managt. Lagos: Frame Unity (Nig) Ltd.

Babalola JB (2003). Fundamentals of Econ. of Edu., Ibadan: Uni. Press

Oguntoye AO (2002) Financing Edu. in Nig. Ibadan: Uni. Press

Nwakpa P (2013). Economics of Edu. Abakaliki: Omega Print Media and Publishing Coy.

Simon HA (1945). Administrative Behavior. New York: The Free Press. 